\author{
밀 잎집눈무늬병원균(Rhizoctonia cerealis)의 배양적 특성과 \\ 국내육성 맥류 품종의 저항성 평가 \\ 이은숙 - 이왕휴 - 강천식 ${ }^{1} \cdot$ 김미정 $^{2} \cdot$ 김태수 $^{1} \cdot$ 박종철 $^{1 *}$ \\ 전북대학교 농생물학과(식물의학연구센터), ${ }^{1}$ 농촌진흥청 국립식량과학원 벼맥류부 맥류사료작물과 \\ ${ }^{2}$ 농촌진흥청 국립식량과학원 전작과
}

\title{
Cultural Characteristics of Rhizoctonia cerealis Isolated from Diseased Wheat Fields and Evaluation of the Resistance of Korean Winter Cereal Crops
}

\author{
Eun-Sook Lee, Wang-Hyu Lee, Chun-Sik Kang', Mi-Jung Kim², Tae-Soo Kim ${ }^{1}$ and Jong-Chul Park ${ }^{1 *}$ \\ College of Agriculture and Life Science, Chonbuk National University, Jeonju 561-756, Korea \\ ${ }^{1}$ Department of Rice and Winter Cereal Crop, NICS, Iksan 570-080, Korea \\ ${ }^{2}$ Upland Crop Research Division, NICS, RDA, Suwon 441-857, Korea \\ (Received on August 16, 2010; Accepted on February 23, 2011)
}

\begin{abstract}
It was identified as a sharp eyespot (Rhizoctonia cerealis) that the isolates from abnormal symptoms in wheat that showed yellowing leaves, necrotic spot on stem base and dead tillers. These isolates have slower growth property and fewer mycelia than Rhizoctonia solani AG-1(1A) (KACC 40106). They showed binuclear cell, same media cultural and DNA characteristics to $R$. cerealis. They caused same symptoms on leaves and stem base appeared in artificial inoculation test, comparing to diseased wheat fields and also affect to maturing of kernels. They have optimal growth temperature and acidity on the artificial media as $20 \sim 25^{\circ} \mathrm{C}$ and $\mathrm{pH} 5 \sim 7$, respectively. In the investigation of varietal resistance of Korean winter cereal crops to sharp eyespot, there was no resistant in wheat cultivars that all materials infected over $20 \%$ diseased ratio. 12 cultivars including 'Anbaekmil', however, considered to moderate resistance with 20 to $30 \%$ infection ratio. The others crops using in feeding, whole crop barley, oat, rye and triticale were resistant below $15 \%$ diseased degree except the rye that showed over $50 \%$ infection rate. It was the first evaluation to sharp eyespot resistance for the Korean feeding crop cultivars. Most tested Korean barley cultivars for malting and food were moderate and susceptible to the sharp eyespot. Only 3 hulled barley, 'Tapgolbori', 'Albori' and 'Seodunchalbori', showed resistance with less than $\mathbf{1 0 \%}$ diseased ratio. All tested naked barley cultivars showed susceptible response to the disease.
\end{abstract}

Keywords : Resistant, Rhizoctonia cerealis, Sharp eyespot, Winter cereal crop

우리나라의 맥류 재배는 주로 보리를 중심으로 이루어 지면서 병해 발생도 주로 깜부기병, 흰가루병, 붉은곰팡 이병 등 진균에 의한 피해가 알려져 왔다. 그러나 90년대 말부터 남부지역 맥주보리 재배지를 중심으로 바이러스 병에 의한 피해가 보고되면서 국내 보리 재배지의 가장 심각한 병해는 바이러스의 발생에 의한 것으로 보고되어

*Corresponding author

Phone) +82-63-840-2243, Fax) +82-63-840-2116

Email) pacc43@rda.go.kr
왔다(소 등, 1991; 박 등, 2005). 하지만 최근 국내 맥류 재배 환경의 변화에 따라 병해 발생 양상도 다양화 되는 경향을 보이고 있다. 월동 후 이상 기상에 따른 기상변화 와 밀 재배와 사료작물 재배 면적 확대에 따른 기주의 다 양화 등으로 곰팡이성 병의 발생도 증가가 예상된다.

보리의 경우 월동기 주요 식량작물로서 병해나 도복 등 내재해에 대해 국내에서도 연구가 되어져 있다(하, 2000). 그러나 밀이나 사료맥류의 경우 급격한 재배면적 증가함 에도 불구하고 그에 따른 병해 발생 등에 대한 국내 연 구는 미흡한 실정이다. 
2009년과 2010년 전라남북도 일부 밀 재배지역에서 잎 의 황화, 지제부 반점 증상과 줄기 고사, 도복 등에 따른 수량 감소 등의 피해가 발생하였고, 원인은 Rhizoctonia cerealis에 의한 밀 잎집눈무늬병(sharp eyespot)으로 확인 되었다. R. cerealis는 밀의 어린 유묘를 죽이거나 모잘록 병을 일으키지만 식물의 줄기 기부에 병반을 더 빈번히 형성하고(Lipps와 Herr, 1982; Clarkson 등, 1983; Cromey 등, 2002) 발병이 지속되면 조기 성숙하거나 도복의 피해 를 입힌다(Cromey 등, 2005). 국내에서는 김 등(1991)에 의해 국내 토양 중 분포와 병원성이 보고되면서 밀 잎집 눈무늬병으로 명명되었다. 또한 현재 우리나라에서 $R$. cerealis에 의한 병해로 밀과 보리의 잎집눈무늬병(sharp eyespot) 외에도, 벼 잎집눈무늬병(sheath eyespot)(Kim과 $\mathrm{Kim}, 1988$ ), 잔디 누른잎마름병(yellow patch)(김 등, 1992) 이 보고되어 있다. 그러나 잔디 누른잎마름병 외에는 그 발병 정도가 적고 경제적 피해가 적어 병원균의 특성이 나 발병 환경, 특히 맥류의 저항성 품종 등에 관한 연구 가 많이 이루어지지 않는 실정이다.

본 시험에서는 병 발생의 특성과 방제에 대한 자료로 활용하기 위해 밀 재배지에서 분리한 R. cerealis의 배양 적 특성과 국내 육성 맥류 품종들에 대한 저항성 정도를 평가하였다.

\section{재료 및 방법}

균 분리 및 동정. 2009년과 2010년 전라북도 전주, 군 산, 익산의 밀 재배단지에서 피해 입은 밀(Fig. 1)을 채집 하여 병반 부위를 건전부위와 함께 약 $5 \times 5 \mathrm{~mm}$ 로 절개 해 표면살균한 후 물한천배지(WA)에 치상하여 $25^{\circ} \mathrm{C}$ 항 온기에서 3 일간 배양하였다. 배지에 자란 균사의 선단을 떼어 감자한천배지(PDA)에 순수분리하고 slant에 계대배
양하여 실험균주로 사용하였다.

동정은 균사 배양 후 균주의 배지상의 생육특성과 균 사의 형태학적 특성을 관찰했으며, Burpee 등(1978)의 염 색방법에 따라 trypan blue(in lactophenol)를 이용해 균사 를 염색한 뒤 균사 내의 2핵 여부를 조사하였다. 비교 균 주로는 한국농업미생물자원센터(KACC)에서 분양받은 R. cerealis(40154)와 R. solani AG-1(1A)(40106)을 사용하 였다. 또한 유전자 특성 확인을 위해 PCR 방법을 이용하 였다. DNA 분리는 Genomic DNA prep kit(SolGent Co.) 를 이용하였다. PCR을 위한 primer는 Nicholson와 Parry (1996)에 의해 보고된 R. cerealis 특이 프라이머 $\mathrm{Rc} 2 \mathrm{~F}$ (5' AAAACTGGCAACCCTTGGTG 3')와 Rc2R(5' TAACTCACCACTCCAGCCGTT 3')을 사용하였다. PCR 증폭은 PCR Premix(Bioneer)에 추출 DNA $2 \mu \mathrm{l}, 10 \mathrm{pmol}$ 의 프라이머 각 $1 \mu l$ 씩, $10 \times \operatorname{buffer(Promega)~} 2 \mu l$ 를 넣고 멸균수로 최종 부피를 $20 \mu \mathrm{l}$ 로 맞춘 뒤 실시하였다. PCR 조건은 $95^{\circ} \mathrm{C} 5$ 분; $95^{\circ} \mathrm{C} 30$ 초, $58^{\circ} \mathrm{C}, 30$ 초, $72^{\circ} \mathrm{C} 2$ 분 40 cycles; $72^{\circ} \mathrm{C}, 5$ 분으로 하였으며, 증폭산물은 $1.5 \%$ 아 가로스 겔에서 전기영동하였다.

병원성 검정. 분리균의 병원성 검정은 분리균주 JS0901 을 접종원으로 사용했으며 이 등(1995)의 방법을 이용하 여 oatmeal 모래배지의 양과 조성을 변형하여 만든 밀기 울모래배지(밀기울:모래:물=3:10:6)를 $100 \mathrm{ml}$ 삼각플라 스크에서 멸균한 뒤 선배양한 JS0901을 $5 \mathrm{~mm}$ cork borer 로 떼어 3 조각씩 넣고 $25^{\circ} \mathrm{C}$ 항온기에서 일주일 배양 후 접종원으로 사용하였다. 식물체는 2009년 10월에 국립식 량과학원 벼맥류부 밀재배포장에 파종하여 재배한 밀('서 둔밀', ‘안백밀', ‘조품밀')을 파종 6개월 후에 포트(50× $33 \times 23 \mathrm{~cm}^{3}$ )에 옮겨 심고 뿌리 활착을 위해 포장과 같은 기상 조건으로 2 주 정도 생육한 뒤 병원성 검정을 위해 식물체를 이식한 토양 위에 접종원을 $40 \mathrm{~g}$ 씩 골고루 뿌

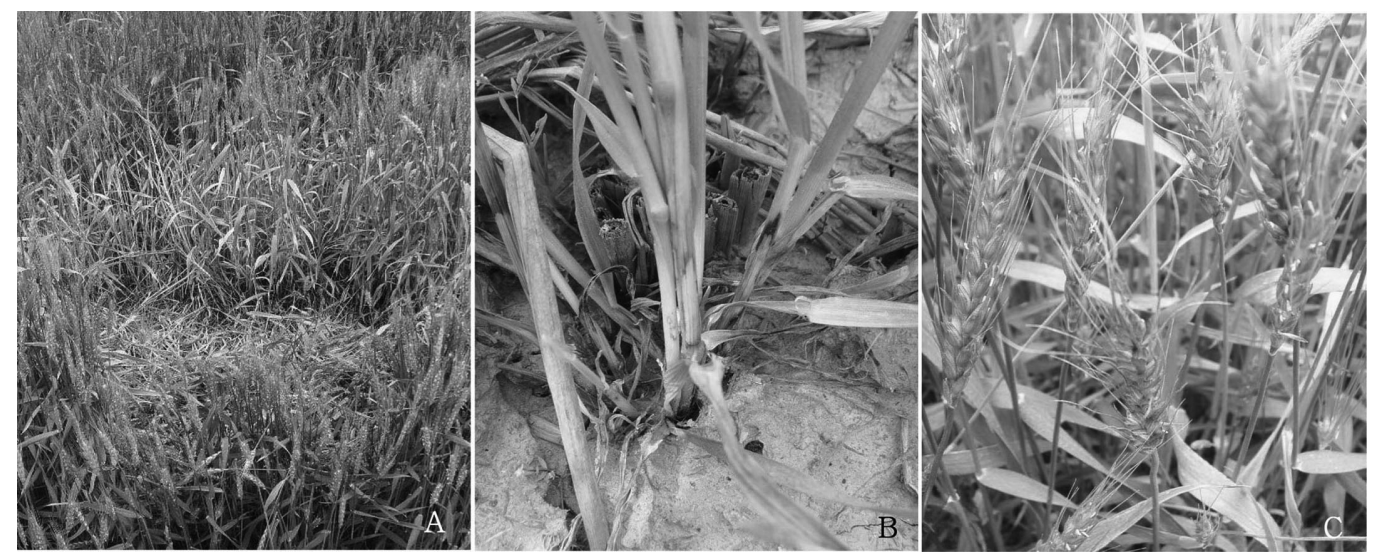

Fig. 1. Symptoms of sharp eyespot infected with Rhizoctonia cerealis on wheat. (A) Lodging on field, (B) Oval-shaped lesions on stem bases, (C) Whitish blight heads. 
려주었다. 발병을 돕기 위해 5일간 비닐을 덮어줬으며 접 종 한 달 후 줄기의 병반 형성 정도를 조사하였다.

R. cerealis의 배양적 특성. R. cerealis의 배양적 특성 은 이 등(1995)의 방법을 참고로 온도와 $\mathrm{pH}$ 의 생육 반응 을 조사하였다. 본 실험은 대조 균주 $(\mathrm{KACC} 40154)$ 와 10 개 분리균주를 $\mathrm{PDA}$ 배지에서 5 일간 $25^{\circ} \mathrm{C}$ 로 선배양한 후 균사 선단을 직경 $5 \mathrm{~mm}$ cork borer로 떼어내 각각 $\mathrm{PDA}$ 에서 생육시킨 후 이용하였다. 온도별 생육 반응은 5,10 , $15,20,25,30,35^{\circ} \mathrm{C}$ 로 조절된 항온기에서 5 일간 배양하 며 각 균총의 생육 길이를 측정하였다. 각 실험은 3 반
복으로 이루어졌다.

$\mathrm{pH}$ 에 따른 균의 생육 특성은 $100 \mathrm{ml}$ 삼각플라스크에 potato dextrose broth(PDB)를 $100 \mathrm{~m}$ 로 조성하여 멸균 후 $0.2 \mu \mathrm{m}$ syringe filter(42213 NN-Nyion Membrance, TITAN) 로 여과한 $1 \mathrm{M}$ 의 $\mathrm{HCl}$ 과 $\mathrm{NaOH}$ 를 이용해 $\mathrm{pH} 4,5,6,7,8$, 9,10 으로 조절하였다. $\mathrm{PDA}$ 에서 선배양한 분리균주 10 균 주의 균사 선단을 $5 \mathrm{~mm}$ cork borer로 떼어내 각 $\mathrm{PDB}$ 배 지에 균사조각을 3개씩 넣은 뒤 $100 \mathrm{rpm}$ 으로 2주간 배양 하였다. 배양된 균사체는 멸균증류수로 수세한 후 여과지 를 이용해 수분을 최대한 제거하고 $90^{\circ} \mathrm{C}$ 건조기에서 5 시

Table 1. Reaction of winter cereal crops cultivars to Rhizoctonia cerealis

\begin{tabular}{|c|c|c|c|c|c|c|c|}
\hline \multicolumn{2}{|c|}{ Varietal kinds } & Cultivar & $\begin{array}{c}\text { Disease incidence }^{\mathrm{a}} \\
(\%)\end{array}$ & Resistance $^{b}$ & Cultivar & $\begin{array}{c}\text { Disease incidence }^{\mathrm{a}} \\
(\%)\end{array}$ & Resistance $^{\mathrm{b}}$ \\
\hline \multirow{15}{*}{\multicolumn{2}{|c|}{ Wheat }} & Anbaekmil & 20.0 & MR & Eunpamil & 47.5 & MS \\
\hline & & Urimil & 22.5 & MR & Gobunmil & 47.5 & MS \\
\hline & & Jinpummil & 24.0 & MR & Keumkangmil & 50.0 & MS \\
\hline & & Dahongmil & 25.7 & MR & Saeolmil & 50.0 & MS \\
\hline & & Olgerumil & 27.5 & MR & Jeokjoongmil & 50.0 & MS \\
\hline & & Chungkyemil & 28.6 & MR & Tapdongmil & 56.5 & MS \\
\hline & & Joeunmil & 28.6 & MR & Namhaemil & 58.3 & MS \\
\hline & & Sukangmil & 31.4 & MR & Baekjoongmil & 60.0 & MS \\
\hline & & Milseoungmil & 32.9 & MR & Hanbaek mil & 60.0 & MS \\
\hline & & Olmil & 32.9 & MR & Jokyungmil & 65.0 & MS \\
\hline & & Sinmichalmil & 33.3 & MR & Dabunmil & 71.7 & $\mathrm{~S}$ \\
\hline & & Alchanmil & 33.8 & MR & Jonongmil & 72.5 & S \\
\hline & & Geurumil & 43.3 & MS & Jopummil & 76.7 & $\mathrm{~S}$ \\
\hline & & Seodunmil & 45.0 & MS & Sinmichalmil-1 & 85.0 & $\mathrm{~S}$ \\
\hline & & Younbaekmil & 46.7 & MS & & & \\
\hline \multirow{3}{*}{\multicolumn{2}{|c|}{$\begin{array}{c}\text { Whole crop } \\
\text { barley }\end{array}$}} & Damibori & 1.7 & $\mathrm{R}$ & Youngyangbori & 7.5 & $\mathrm{R}$ \\
\hline & & Yuyeonbori & 3.8 & $\mathrm{R}$ & Woohobori & 12.9 & MR \\
\hline & & Sunwoobori & 4.4 & $\mathrm{R}$ & & & \\
\hline \multicolumn{2}{|c|}{ Oat } & Samhan & 7.8 & $\mathrm{R}$ & Johan & 12.2 & MR \\
\hline \multicolumn{2}{|c|}{ Rye } & Gokwoo & 50.0 & MS & Martin & 62.2 & MS \\
\hline \multicolumn{2}{|c|}{ Triticale } & Sinyoung & 15.6 & MR & & & \\
\hline \multirow{10}{*}{ Barley } & \multirow{2}{*}{ Naked } & Saessalbori & 41.7 & MS & Baegdongbori & 82.5 & $\mathrm{~S}$ \\
\hline & & Namhobori & 77.5 & $\mathrm{~S}$ & Pungsanchalssalbori & 86.7 & $\mathrm{~S}$ \\
\hline & \multirow{5}{*}{ Hulled } & Tapgolbori & 3.3 & $\mathrm{R}$ & Keunal No.1 & 21.1 & MR \\
\hline & & Albori & 8.9 & $\mathrm{R}$ & Olbori & 32.5 & MR \\
\hline & & Seodunchalbori & 10.0 & $\mathrm{R}$ & Saeolbori & 33.3 & MR \\
\hline & & Chalbori & 16.3 & MR & Saekangbori & 37.9 & MR \\
\hline & & Saealbori & 20.0 & MR & & & \\
\hline & \multirow{3}{*}{ Malting } & Hojinbori & 22.2 & MR & Dusan 29 & 33.3 & MR \\
\hline & & Hopumbori & 24.0 & MR & Sinhobori & 38.9 & MR \\
\hline & & Jinyangbori & 27.1 & MR & & & \\
\hline
\end{tabular}

${ }^{\mathrm{a}}$ Disease incidence (\%): Numbers of diseased stem/Numbers of total stem $\times 100$.

${ }^{\mathrm{b}}$ Resistance: $\mathrm{R}=$ below $10 \%$ of disease incidence, $\mathrm{MR}=11 \sim 40 \%$ of disease incidence, $\mathrm{MS}=41 \sim 70 \%$ of disease incidence, $\mathrm{S}=\mathrm{above} 71 \%$ of disease incidence. 
간 이상 건조하여 더 이상 무게가 변하지 않는 상태가 되 면 건물중을 측정하였다. 실험은 3 반복으로 실시하였다.

맥류 품종별 저항성 평가. 국내 육성 맥류 품종에 대 한 저항성 평가를 위해 밀 29 , 보리 24 , 귀리 2 , 호밀 2, 그리고 트리티케일 1 품종 등 총 58 품종을 이용하였다 (Table 1). 각각의 맥종별 품종은 포트에서 일 주일간 생 육시킨 후 $10 \mathrm{~cm}$ 정도의 유묘에 접종원을 약 $20 \mathrm{~g}$ 씩 접 종하였다. 발병 유도를 위해 접종 후 3 일간 비닐을 덮어 습도를 유지하였으며 7일 후에 모잘록 증상을 조사하여 저항성 정도를 평가하였다. 발병률은 전체 줄기 수에 대 한 발병 줄기 수 비율로 산출하였고, 저항성 평가는 발병 주율을 기준으로 저항성(R: $10 \%$ 이하), 중도저항성(MR: 11 40\%), 중도감수성(MS: 41 70\%), 감수성(S: $71 \%$ 이상) 의 4 단계로 판별하였다. 실험은 3 반복으로 실시하였다.

\section{결과 및 고찰}

균 분리 및 동정. 밀 병반에서 분리된 Rhizoctonia균은 R. solani AG-1(1A)(KACC 40106)에 비해 생장 속도가 현 저히 느렸으며, 배지 상에서 크림색을 띄고 기중 균사는 약간만 형성하고 대부분의 균사가 배지 표면에 깔려 자랐 으며 분생포자를 형성하지 않았다. 일부 균주에서는 시간 이 지남에 따라 진갈색 검은색의 균핵을 형성하기도 하 였는데, 이 결과는 정 등(1991)이 보고한 R. cerealis의 생 육 특성과 같았다. 현미경 하에서는 Rhizoctonia spp.의 특 징인 직각분지와 분지지점의 균사가 잘록한 형태를 관찰 할 수 있었으며 균사 내 핵 수 관찰 결과 모든 분리균에 서 세포 당 두 개의 핵을 관찰할 수 있었다(Fig. 2). 병원 균의 $\mathrm{DNA}$ 에 대한 $\mathrm{PCR}$ 검정 결과에서 분리 균주들은 모 두 표준균주(R. cerealis, KACC 40154)와 같은 $800 \mathrm{bp}$ 의 증폭산물(Nicholson와 Parry, 1996)이 확인된 반면, 대조균 인 R. solani(KACC 40106)는 검출되지 않았다(Fig. 3). 이 와 같은 결과들로 밀 이상 증상 병반에서 분리된 분리균 주는 R. cerealis로 동정되었다. 밀기울 모래배지에 배양한

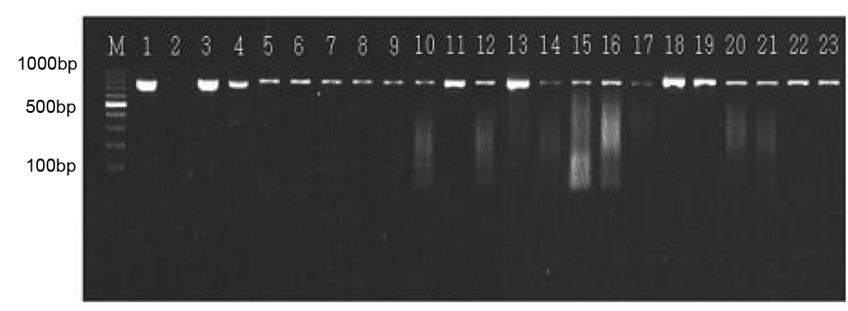

Fig. 3. Identification of Rhizoctonia cerealis by PCR amplification method. The product size $800 \mathrm{bp}$ indicates amplification of the $R$. cerealis DNA part. M means $100 \mathrm{bp}$ DNA ladder and Lane $1, R$. cerealis (KACC 40154); Lane 2, R. solani (KACC 40106); Lane $3 \sim 23$, isolates from diseased wheats.

접종원(JS0901)을 처리한 결과 밀의 지제부 줄기에서 밀 잎집눈무늬병의 특징적인 병징을 확인할 수 있었다. 병징 은 중앙이 크림색이고 테두리는 갈색을 가진 타원형의 병 반이었으며, 한 달 이상 접종상태로 둔 결과 지제부가 부 패되고 잎이 끝부터 갈변되기 시작하였으며 분얼된 줄기 를 비롯하여 밀 전체가 갈변 또는 고사됐고 밀의 이삭은 수정이나 등숙이 이루어지지 않아 대부분이 백수 증상을 보였다. 이는 기존의 병원성 검정 보고(Lipps와 Herr, 1982) 와도 같은 결과였다. 또한 줄기 밀도가 높고 심한 고사가 발생한 경우에는 밀 지제부에서 하얀색 또는 크림색의 균 핵이 일부 관찰되었으며 포자는 관찰되지 않았다. 한편 접 종부위의 병징 발생부위에서 균을 분리한 결과에서도 접 종원과 같은 균이 분리되어 R. cerealis로 확인되었다. 이 와 같이 균의 형태적, 유전자적 특성과 병원성 검정을 통 해 밀 재배단지에서 지제부 고사와 잎 황화 증상은 $R$. cerealis에 의한 밀 잎집눈무늬병으로 확인하였다.

R. cerealis의 배양적 특성. 분리된 R. cerealis의 각 온 도별 생장 길이를 측정한 결과(Table 2), 최적온도는 $20 \sim 25^{\circ} \mathrm{C}$ 로 확인되었으며 $30^{\circ} \mathrm{C}$ 에서부터는 균총의 생장 길이가 급 격히 감소하고 $35^{\circ} \mathrm{C}$ 에서는 전혀 자라지 못했다. 또한 $15^{\circ} \mathrm{C}$ 에서도 비교적 좋은 생육을 보여 저온 적응성이 강한 것 으로 조사되었다. 이는 균사생장은 전체적으로 온도가 낮 은 범위에서 생육이 활발하였다는 기존의 보고와도 같았

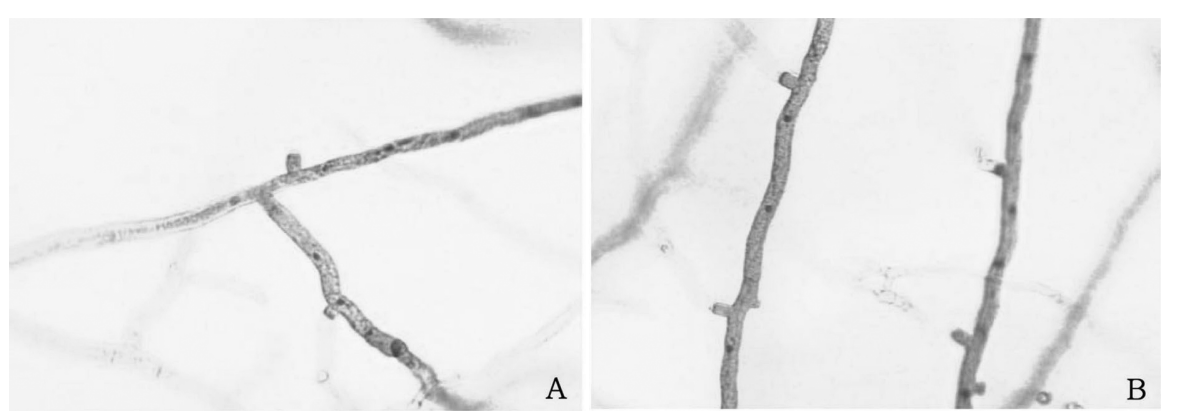

Fig. 2. Mycelium growth and binuclear hyphae characterization of the isolates. It was stained with $0.4 \%$ trypan blue in lactophenol. (A) distinct right angle branching of the hyphae growth of the Rhizoctonia cerealis, (B) Binuclear hyphae cell $(\times 400)$. 
Table 2. Mycelium growth of Rhizoctonia cerealis isolate from disease wheat at various temperature

\begin{tabular}{cccccccc}
\hline \hline \multirow{2}{*}{ Fungal mycelium growth } & \multicolumn{7}{c}{ Temperature $\left({ }^{\circ} \mathrm{C}\right)$} \\
\cline { 2 - 8 } & 5 & 10 & 15 & 20 & 25 & 30 & 35 \\
\hline KACC 40154 (mm) & 5.0 & 9.8 & 16.5 & 23.8 & 25.5 & 14.0 & 0.0 \\
Isolates (mm) & 3.8 & 9.5 & 15.7 & 24.6 & 26.9 & 4.4 & 0.0 \\
\hline
\end{tabular}

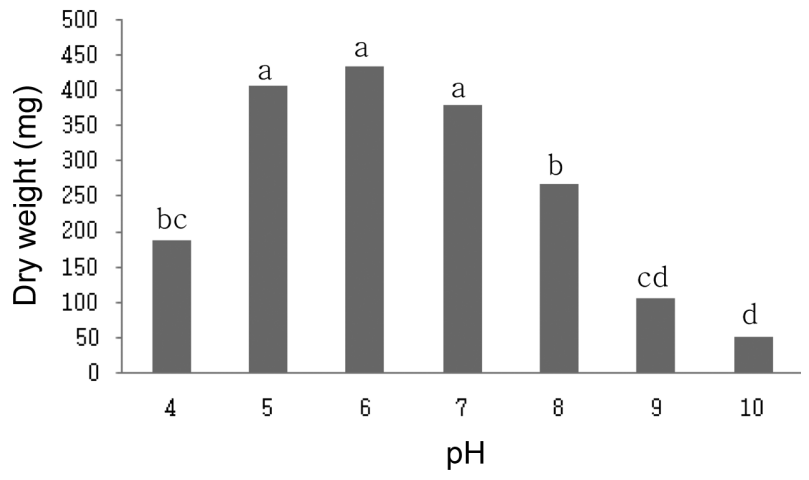

Fig. 4. Mycelium growth at various $\mathrm{pH}$ conditions of Rhizoctonia cerealis isolates from diseased wheat. The same letter within columns means no significant differences between the treatments by Duncuns multiple range test $(P=0.05)$.

다(김 등, 1992; 이 등, 1995). 또한 이 결과는 2009년과 2010년 밀 재배포장에서 발병 시기에 월동 후 3 4월경 이상 저온 시기에 급격히 발생된 것으로 보아 차갑고 습 한 조건에서 일반적으로 발병이 잘되는 보고(Cromry 등, 2002)와도 같은 결과로 나타났다.

분리균주들의 $\mathrm{pH}$ 에 따른 생육을 조사한 결과(Fig. 4), 대체로 약산성에서 활발했는데 $\mathrm{pH}$ 5 7 사이가 생육이 좋 은 것으로 나타났다. $\mathrm{pH}$ 6에서 균의 생육량이 평균 건물 중 $430 \mathrm{mg}$ 으로 가장 생장이 좋았으나 $\mathrm{pH} 5$ 와 7에서 각 각 평균 건물중이 $405 \mathrm{mg}$ 과 $378 \mathrm{mg}$ 으로 나타났다. 반면 강산성인 $\mathrm{pH} 4$ 와 염기조건인 $\mathrm{pH}$ 9와 10 에서는 건물중이 $200 \mathrm{mg}$ 이하로 나타나 이 범위에서는 생육이 저하되는 것으로 확인되었다. 이 결과에서 R. cerealis는 약산성토 양이 생육에 적합한 환경 조건임이 확인되었다. R. cerealis 에 대한 $\mathrm{pH}$ 별 생육 반응은 국내에서는 미흡한 실정으로 이 결과는 국내 답리작의 $\mathrm{pH} 5.6$ 산성도(정 등, 1998)와 병의 발생에 대한 관련성 조사에 대한 기초 정보를 제공 할 수 있을 것으로 생각된다. 또한 최근 월동 후 이상 기 상에 따른 본 병의 포장에서의 발생과 피해에 대한 지속 적인 조사도 필요 할 것으로 나타났다.

국내 육성 맥류 품종의 저항성 검정. 밀 잎집눈무늬병 에 대해 국내 육성 품종에 대한 저항성 검정을 수행하였 다. 밀 품종 검정 결과 검정한 29 품종에서 $20 \%$ 이상의 발병률로 저항성이 확인되지 않았다. 안백밀 등 12 품종이
발병률 20 30\%의 중도저항성을 보였으나 그루밀 등 17 품종은 $40 ~ 80 \%$ 이상으로 감수성을 보였다(Table 1). 사 료용으로 이용되는 청보리, 귀리, 호밀, 트리티케일 검정 결과에서는 청보리, 귀리, 트리티케일에서는 발병률 $15 \%$ 이하로 저항성인 것으로 나타났으나, 호밀 2품종은 $50 \%$ 이상의 발병률을 보여 감수성으로 나타났다. 한편 식용 및 맥주용 보리 검정 결과 겉보리 9품종 중 '탑골보리', '알보리', '서둔찰보리' 등 3 품종이 발병률 $10 \%$ 이하의 저 항성을 보였으며, 나머지 6 개 겉보리와 5 개 맥주보리 전 체 검정 품종은 중도 저항성을 보였다. 그러나 검정 쌀보 리 품종들은 감수성인 것으로 나타났다. 하 등(2000)은 국 내 보리 품종을 대상으로 쌀보리는 '찰쌀보리', 겉보리는 '조강보리' 등 4품종이 저항성이었다고 보고하였다. 본 시 험에서는 주로 밀과 사료용 맥류 품종을 대상으로 수행 한 이유로 기존의 보고와 비교가 어려웠다. 겉보리의 저 항성 정도는 본 시험에서도 비슷한 결과를 보였으나, 최 근에 육성된 품종들을 포함하여 맥류 전 품종에 대한 저 항성 평가도 필요할 것으로 보인다. 이 결과들은 맥류 재 배지 토양에서 분리한 R. cerealis가 보리와 밀에 병원성 을 나타낸다는 김 등(1991)의 보고와 같았다. 귀리나 트 리티케일, 호밀에서의 발병은 국내에서는 보고되어 있지 않다. 이 결과로 보아 R. cerealis에 의해 맥류 전체 맥종 들이 감염과 발병을 일으킬 수 있으며, 품종간 발병 정도 가 차이가 있는 것으로 확인되었다. 특히, 밀과 쌀보리는 국내 품종들이 감수성인 것으로 나타나 저항성 품종 개 발에 대한 관련 연구가 특히 필요할 것으로 생각된다. 세 계적으로 R. cerealis의 발병으로 인해 일반적으로 큰 피 해는 없는 것으로 알려져 있으나(Colbach 등, 1997), 추 파 밀의 경우 발병에 좋은 조건에서는 심한 발생으로 큰 피해를 일으키기도 한다(Clarkson과 Cook, 1983). 최근 2005 2008년 중국에서는 이 병에 의해 십억 위안의 경제 적 피해가 보고되었다(Chen 등, 2008). 또한 병 발생 정 도는 파종기와도 관련이 있어 발생 상습지에서 추파를 권 장하지 않는 보고(Cromey 등, 2005)로 보아, 추파를 주로 하는 국내에서 병의 발생과 피해가 더 크게 나타날 수 있 을 것으로 생각된다. 국외에서의 밀 잎집눈무늬병 저항성 관련 연구는 품종 선발(Cromey 등, 2005), 특히 중국에서 DNA marker 탐색, 품종 육성 등의 연구가 활성화 되어 
있다(Ren 등, 2004; Zhang 등, 2004; Wu 등, 2005). 국내 와 국외의 맥류 재배는 파종기, 품종, 토양, 재배기술 등 재배환경에 차이가 있어 병 발생과 피해가 다르게 나타 날 것으로 보인다. 이에 따라 밀 잎집눈무늬병의 국내 발 생 현황이나 원인 등에 정밀한 조사와 저항성 품종 육성 및 방제법 등 관련 연구가 더욱 필요할 것으로 생각된다.

\section{요 약}

밀의 잎의 황화와 줄기 고사 증상이 발생한 포장에서 분리한 균을 동정한 결과 배지 생육 반응, 형태학적 - 유 전자적 특성과 병원성, 균의 DNA 검정 결과 밀 잎집눈 무늬병을 일으키는 Rhizoctonia cerealis로 확인되었다. $R$. cerealis의 온도와 $\mathrm{pH}$ 에 따른 배양적 특성을 조사한 결과 생육 최적 온도는 $20 \sim 25^{\circ} \mathrm{C}$ 로 약간 저온성인 것으로 확인 되었다. $\mathrm{pH}$ 에 따른 생육 반응 조사 결과는 $\mathrm{pH}$ 5 7에서 생육이 좋아 대체로 약산성에서 활발한 특징을 보였다.

밀 잎집눈무늬병에 대해 국내 육성 맥류 품종에 대한 저항성 검정을 수행하였다. 밀 품종 검정 결과 검정한 29 품종에서 $20 \%$ 이상의 발병률로 저항성이 확인되지 않았 다. 안백밀 등 12 품종이 발병률 20 30\%의 중도저항성을 보였으나 ‘그루밀' 등 17 품종은 $40 \sim 80 \%$ 이상으로 감수성 을 보였다. 사료용으로 이용되는 청보리, 귀리, 호밀, 트 리티케일 검정 결과에서는 호밀 2품종에서만 $50 \%$ 이상 의 발병률을 모여 감수성으로 나타났으나, 청보리, 귀리, 트리티케일에서는 발병율 $15 \%$ 이하로 저항성인 것으로 나타났다. 귀리나 트리티케일, 호밀의 발병과 저항성 평 가는 국내에서 처음 이루어졌다. 한편 식용 및 맥주용 보 리 검정 결과 겉보리 9품종 중 '탑골보리', '알보리', '서 둔찰보리' 등 3 품종이 발병률 $10 \%$ 이하의 저항성을 보였 으며 6 개 겉보리와 5 개 맥주보리 전체 검정 품종은 중도 저항성을 보인 반면 검정 쌀보리 품종들은 감수성인 것 으로 나타났다.

\section{참고문헌}

김완규, 조원 대, 이영희. 1991. 4종의 기주에서 분리한 Rhizoctonia cerealis 균주들의 균사융합 및 병원성. 한국식물 병리학회지 7: 52-54.

김진원, 심규열, 김호준, 이두형. 1992. 잔디 잎마름증상(Yellow patch)을 일으키는 2핵성 Rhizoctonia의 동정 및 병원성. 한 국잔디학회지 6: 99-112.

박종철, 서재환, 김양길, 김정곤. 2005. 국내 맥류재배지의 바이 러스병 발생 현황과 BaYMV-Ik와 BaMMV에 대한 저항성 유전자의 반응 검정. 한국작물학회지 50: 197-204.
소인영, 정성수, 이귀재, 오양호. 1991. 보리호위축바이러스 (BaYMV)의 매개체 검정 및 방제법에 관한 연구(II). 농시논 문집 34: 75-83.

이두형, 최양윤, 이재흥, 김 진원. 1995. 잔디에서 분리한 Rhizoctonia spp.의 동정과 병원성. 한국균학회 23: 257-265. 정병간, 조국현, 윤을수, 윤정희, 김유학. 1998. 우리나라 논土壤 의 化學的 特性 分析. 한국토양비료학회지 31: 246-252.

정영륜, 김흥태, 김태준, 조광연. 1991. 한국들잔디(Zoysiagrass) 와 bentgrass의 병반에서 분리된 Rhzoctonia spp.의 배양특성 과 병원성. 한국식물병리학회지 7: 230-235.

Burpee, L. L., Sanders, P. L., Cole, Jr. H. and Kim, S. H. 1978. A staining technique for nuclei of Rhizoctonia solani and related fungi. Mycologia 70: 1281-1283.

Chen, L., Zhang, Z. Y., Liang, H. X., Liu, H. X., Du, L. P., Xu, H. and Xin, Z. 2008. Overexpression of TiERF1 enhances resistance to sharp eyespot in transgenic wheat. J. Exp. Bot. 59: 4195-4204.

Clarkson, J. D. S. and Cook, R. J. 1983. Effect of sharp eyespot (Rhizoctonia cerealis) on yield loss in winter wheat. Plant Pathology 32: 421-428.

Colbach, N., Lucas, P., Cavelier, N. and Cavelier, A. 1997. Influence of cropping system on sharp eyespot in winter wheat. Crop Protection 15: 415-422.

Cromey, M. G., Butler, R. C., Munro, C. A. and Shorter, S. C. 2005. Susceptibility of New Zealand wheat cultivars to sharp eyespot. Plant Pathology 58: 268-272.

Cromey, M. G., Cromry, R. C., Boddington, H. J. and Moorhead, A. R. 2002. Effects of sharp eyespot on yield of wheat (Triticum aestivum) in New Zealand. New Zealand J. Crop and Hort. Sci. 30: 9-17.

Kim, W. G. and Kim, C. K. 1988. Density of over wintered sclerotia in paddy fields in Korea, viability of the sclerotia and pathogenicity of the sclerotial fungi. Kor. J. Plant Pathol. 4: 207-217.

Lipps, P. E. and Herr, L. J. 1982. Etiology of Rhizoctonia cerealis in sharp eyespot of wheat. Phytopathology 72: 1574-1577.

Nicholson, P. and Parry, D. W. 1996. Development and use of a PCR assay to detect Rhizoctonia cerealis the cause of sharp eyespot in wheat. Plant Pathology 45: 872-883.

Ren, L. J., Cai, S. B., Tang, T., Wu, J., Z., Zhou, M. P., Yan, W., $\mathrm{Ma}, \mathrm{H}$. X. and Lu, W. Z. 2004. SSR markers linked resistance QTLs to sharp eyespot (Rhizoctonia cerealis) in wheat. $J$. Yandzhou Uni. 2004-04.

Wu, J. Z., Yan, W., Cai, S. B., Ren, L. J. and Tang, T. 2005. Genetic analysis of sharp eyespot resistance by using major gene plus polygene mixed inheritance analysis in wheat (Triticum aestivum). Jiangsu J. Agri. Sci. 2005-01.

Zhang, X. C., Li, S. S., Zhao, X. H. and Li, R. J. 2004. Genetic analysis on resistance to sharp eyespot by using fifteen populations of recombinant inbred lines in wheat. J. Acta Tri. Crops 2004-03. 